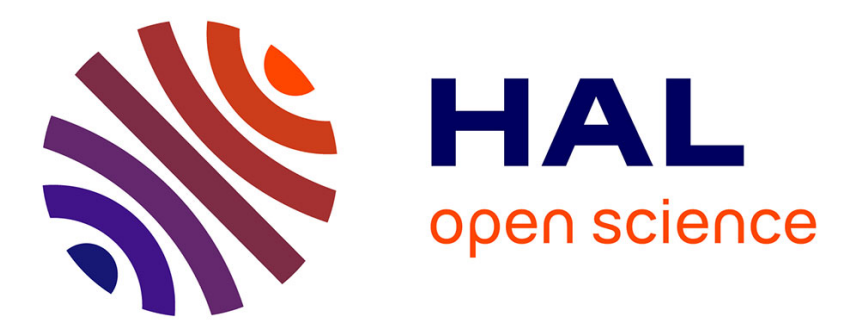

\title{
UV absorption properties of ceria-modified compositions within the fluorite-type solid solution CeO2-Y6WO12
}

François Cheviré, Francisco Muñoz, Charles F. Baker, Franck Tessier, Olivier Larcher, Souhir Boujday, Christophe Colbeau-Justin, Roger Marchand

\section{- To cite this version:}

François Cheviré, Francisco Muñoz, Charles F. Baker, Franck Tessier, Olivier Larcher, et al.. UV absorption properties of ceria-modified compositions within the fluorite-type solid solution CeO2Y6WO12. Journal of Solid State Chemistry, 2006, 179 (10), pp.3184-3190. 10.1016/j.jssc.2006.06.013 . hal-00868037

\section{HAL Id: hal-00868037 https://hal.science/hal-00868037}

Submitted on 21 Sep 2015

HAL is a multi-disciplinary open access archive for the deposit and dissemination of scientific research documents, whether they are published or not. The documents may come from teaching and research institutions in France or abroad, or from public or private research centers.
L'archive ouverte pluridisciplinaire HAL, est destinée au dépôt et à la diffusion de documents scientifiques de niveau recherche, publiés ou non, émanant des établissements d'enseignement et de recherche français ou étrangers, des laboratoires publics ou privés. 


\section{Graphical abstract:}

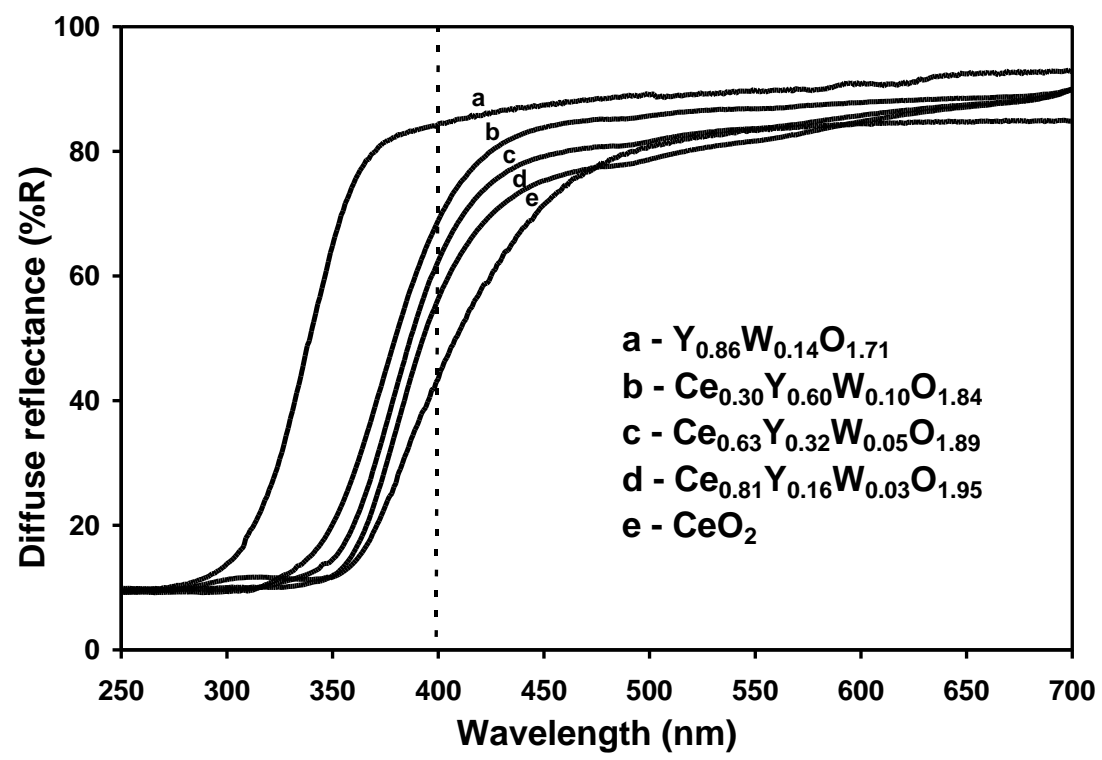




\title{
UV absorption properties of ceria-modified compositions within the fluorite-type solid solution $\mathrm{CeO}_{2}-\mathrm{Y}_{6} \mathrm{WO}_{12}$.
}

François Cheviré ${ }^{\mathrm{a}}$, Francisco Muñoz ${ }^{\mathrm{a}}$, Charles F. Baker ${ }^{\mathrm{a}}$, Franck Tessier ${ }^{\mathrm{a}, *}$ Olivier Larcher ${ }^{\mathrm{a}}$, Souhir Boujday $^{\mathrm{b}}$, Christophe Colbeau-Justin ${ }^{\mathrm{b}}$, Roger Marchand ${ }^{\mathrm{a}}$.

a UMR CNRS 6226 "Sciences Chimiques de Rennes", équipe "Verres et Céramiques", Université de Rennes 1, 35042 Rennes cedex, France

Phone: +332232362 56

Fax: +33223235683

* Franck.Tessier@univ-rennes1.fr

b Laboratoire d'Ingénierie des Matériaux et des Hautes Pressions, CNRS UPR 1311, Université Paris 13, 99 Avenue J. B. Clément, 93430 Villetaneuse, France

\section{Keywords}

Modified ceria, solid solution, amorphous citrate route, optical properties, UV absorbers.

\begin{abstract}
A new fluorite-type solid solution domain has been evidenced in the system (1-x) $\mathrm{CeO}_{2}$ $\mathrm{x} / 7 \mathrm{Y}_{6} \mathrm{WO}_{12} \square_{2}$ using the amorphous citrate route. All the studied phases $(0 \leq \mathrm{x} \leq 1)$ crystallize in a cubic-type symmetry. Diffuse reflectance spectra reveal a strong optical absorption between 380 and $400 \mathrm{~nm}$. All substituted compositions spectral selectivities are estimated suitable for application as inorganic UV absorbers. The non linear variation observed in the optical gap values between $\mathrm{Y}_{6} \mathrm{WO}_{12}$ and $\mathrm{CeO}_{2}$ is attributed to the presence of the cerium 4f-block band. Additionally, TRMC and phenol photodegradation analyses carried out on the $\mathrm{Ce}_{0.81} \mathrm{Y}_{0.16} \mathrm{~W}_{0.03} \mathrm{O}_{1.95} \square_{0.05} \quad(\mathrm{x}=0.19)$ composition do not indicate any photocalatytic activity for this material.
\end{abstract}




\section{Introduction}

Oxides with fluorite-related structure have various and unique properties such as ionic conductivity, transformation toughening, and lead to phase transformations in zirconia and hafnia solid solutions $[1,2]$. As an illustration, yttrium tungstate $\mathrm{Y}_{6} \mathrm{WO}_{12} \square_{2}$ has a very high melting point $\left(2360 \pm 20^{\circ} \mathrm{C}\right)$ and crystallizes at ambient temperature in a rhombohedral symmetry-type with ordering in both the cationic $\left(\mathrm{Y}^{3+} / \mathrm{W}^{6+}\right)$ and anionic $\left(\mathrm{O}^{2-} /\right.$ vacancies $)$ sub-networks [3]. As reported in literature, a phase transition from rhombohedral to cubic occurs at the temperature of $1765 \pm 25^{\circ} \mathrm{C}$ above which the unit cell corresponds to a regular fluorite lattice that implies a random distribution in the cationic and anionic sub-networks $[4,5]$. Recently Yoshimura et al. have shown that cubic $\mathrm{Y}_{6} \mathrm{WO}_{12} \square_{2}$ can be obtained and stabilized as a metastable phase at low temperature $\left(600{ }^{\circ} \mathrm{C}\right)$ using a complexation-calcination route [6]. These authors have also reported the existence of solid solutions with cubic fluorite-type structure in the $\mathrm{ZrO}_{2}-\mathrm{Y}_{6} \mathrm{WO}_{12} \square_{2}$ system [7].

Here, we report the synthesis of powders in the $\mathrm{CeO}_{2}-\mathrm{Y}_{6} \mathrm{WO}_{12}$ solid solution using the amorphous citrate route [8]. The optical properties of these modified-ceria based materials were investigated in order to characterize their potential abilities as inorganic UV absorbers. To date, zinc and titanium oxides are the main compounds used as inorganic anti-UV. However, they present two major drawbacks: (i) - they both manifest high photocatalytic activity under UV irradiation that can induce a photodegradation of the organic medium in which they are dispersed (varnish, paper, ...); (ii) - they were originally optimized to be used as white pigments, in that way they exhibit high refractive indexes to diffuse visible light: titanium oxides - rutile: $n=2.7$, anatase: $n=2.5$ [9]. As a consequence, a whitening of the medium is generally observed which limits the use of such compounds in the case where a clear and colorless UV shield is needed (wood finishes, ...). In the last years, numerous papers have studied cerium oxide $\mathrm{CeO}_{2}$ as a possible alternative $(\mathrm{Eg}=3.2 \mathrm{eV}$, $\mathrm{n}=2.2$ ) [9-11]. Ceria manifests a lower photocatalytic activity than that of zinc and titanium oxides but it still has an important catalytic behavior for oxidation of organic compound limiting its commercial use [12]. Additionally, it also slightly absorbs in the visible range producing a yellowish coloring in the products, mostly undesired in specific applications. Recently, Yabe et al. have shown that the substitution of larger and/or less positively charged cations $\left(\mathrm{Ca}^{2+}, \mathrm{Sr}^{2+}, \mathrm{Ba}^{2+}\right.$, $\mathrm{Mg}^{2+}, \mathrm{Zn}^{2+}$ ) for $\mathrm{Ce}^{4+}$ can bring a suitable solution to the drawbacks of ceria [13]. 


\section{Experimental}

Oxide synthesis. Among numerous chimie douce type processes which have been developed to prepare oxide powders in order to improve their quality (purity, chemical homogeneity, etc.) and their reactivity, the process involving citric acid as a complexing agent was preferentially used. It is not, strictly speaking, a classic sol-gel process in the usual sense that the gel is not formed by a metal-oxygen-metal network, but rather from calcination of metal-organic complexes, thus producing ultra fine reactive powders with an excellent chemical homogeneity [8]. Five compositions were investigated in the system (1-x) $\mathrm{CeO}_{2}-\mathrm{x} / 7 \mathrm{Y}_{6} \mathrm{WO}_{12} \square_{2}$ with $\mathrm{x}=0,0.19$, $0.37,0.70$ and 1 ; the $\mathrm{x}$ values have been determined to correspond to the ratio $\mathrm{Ce} /(\mathrm{Ce}+\mathrm{Y})=1,5 / 6$, 4/6, 2/6 and 0 respectively. Yttrium sesquioxide $\left(\mathrm{Y}_{2} \mathrm{O}_{3}, 99.99 \%\right.$, Alfa Aesar), cerium chloride $\left(\mathrm{CeCl}_{3} \cdot 8 \mathrm{H}_{2} \mathrm{O}\right.$, Aldrich) and tungstic acid $\left(\mathrm{H}_{2} \mathrm{WO}_{4}, 99 \%\right.$, Aldrich) were used as starting materials and dissolved separately in diluted nitric acid or in an ammonia solution. Citric acid $\left(\mathrm{C}_{6} \mathrm{H}_{8} \mathrm{O}_{7}\right.$, Merck, > 99\%) dissolved in a minimum amount of water was added to the solution in the proportion of one mole per cation valence, the addition being followed by a 30 min stirring step at $120{ }^{\circ} \mathrm{C}$. Since the complexation of cations by citric acid is improved at $\mathrm{pH} \geq 7$, the acidic solution that contained yttrium and cerium ions was neutralized by an ammonia solution (25\%, Merck) [14]. With increasing the $\mathrm{pH}$, the color of the solution changed from colorless to yellow indicating the oxidation of the $\mathrm{Ce}^{3+}$ ions to $\mathrm{Ce}^{4+}$. Then $\mathrm{Y}^{3+} / \mathrm{Ce}^{4+}$ and $\mathrm{W}^{6+}$ solutions were mixed together and stirred at $150{ }^{\circ} \mathrm{C}$ for $15 \mathrm{~min}$ to promote chelate formation. The liquid was progressively heated to $250{ }^{\circ} \mathrm{C}$, leading after $15 \mathrm{~h}$ to an expanded black solid residue. This product was finally ground and calcined for $2 \mathrm{~h}$ at different temperatures between $400{ }^{\circ} \mathrm{C}$ and $1000{ }^{\circ} \mathrm{C}$ in an alumina crucible in order to identify the phases formed during the pyrolysis process. A final heating at $1000{ }^{\circ} \mathrm{C}$ for $15 \mathrm{~h}$ was carried out to obtained well crystallized samples for structural and optical characterizations.

X-ray diffraction. XRD powder patterns were recorded using a Philips PW3710 diffractometer operating with $\mathrm{Cu} \mathrm{K}_{\alpha}$ radiation $(\lambda=1.5418 \AA)$. X'PERT softwares -Data Collector and Graphics and Identify- were used, respectively, for recording, analysis, and phase matching of the patterns. The lattice parameters were refined using Dicvol04 [15].

UV-Vis spectrophotometry. Diffuse reflectance spectra were collected using a Varian Cary 100 Scan spectrometer equipped with the Varian WinUV software and the integrating sphere Labsphere (DRC-CA-30I). Prior to measurements, the absolute reflectance of the samples was calibrated with a certified "spectralon" standard (Labsphere Cie). Experimental data were collected within the 250-800 $\mathrm{nm}$ range with $1 \mathrm{~nm}$ step and $0.5 \mathrm{~s}$ integration time. The position of the 
absorption edge was determined graphically at the inflexion point of the curve and the value of the optical gap using the theory of Kubelka-Munk [16].

Refractive indexes. An estimation of the refractive index with an error of 5-10\% is possible using the Gladstone-Dale formula: $\mathrm{n}=1+\rho \Sigma \mathrm{m}_{\mathrm{i}} \mathrm{a}_{\mathrm{i}}$ where $\rho$ is the density of the compound $\mathrm{A}^{\mathrm{a}+}{ }_{\mathrm{x}} \mathrm{B}^{\mathrm{b}+}{ }_{\mathrm{y}} \mathrm{O}_{\mathrm{z}}, \mathrm{m}_{\mathrm{i}}$ is the weight fraction and $\mathrm{a}_{\mathrm{i}}$ is the refraction coefficient of the binary oxides $\mathrm{A}^{\mathrm{a}+} \mathrm{O}_{\frac{\mathrm{a}}{2}}$ and $\mathrm{B}^{\mathrm{b}+} \mathrm{O} \frac{\mathrm{b}}{2}$ [17]. The refractive index of a complex oxide can be considered as the sum of the contributions of each binary oxide that constitutes the compound. The $a_{i}$ coefficients were empirically determined for most of the binary oxides from their refractive indexes [18]. Jaffe has shown that very good results can be obtained for minerals with more or less complex compositions. For example, the estimated refractive index of calcium tungstate $\mathrm{CaWO}_{4}(1.921)$ is very close to the experimental value $n=1.925$ [19].

Photocatalytic tests. The evaluation of the non-photocatalytic behavior of the substituted composition $\mathrm{Ce}_{0.81} \mathrm{Y}_{0.16} \mathrm{~W}_{0.03} \mathrm{O}_{1.95} \square_{0.05}$ was carried out in two steps. First, Time Resolved Microwave Conductivity (TRMC) was used for the investigation of the charge carriers lifetimes in the compound. In a second step, the photocatalytic activity of the material was further studied through the photodegradation of phenol. Basically, the powder is dispersed in an aqueous solution of phenol under vigorous stirring and oxygen bubbling. The suspension is then irradiated using a UV lamp and samples are withdrawn after various reaction times, filtrated and analyzed by UVVisible absorption spectrometry (Varian Cary 300) to follow the concentration of phenol and the appearance of any photodegradation products. Principles and experimental set up of both analysis are fully described in ref. [20] and [21].

\section{Results and Discussion}

The first and main objective of that work is to evidence a solid solution domain between ceria and the metastable cubic $\mathrm{Y}_{6} \mathrm{WO}_{12} \square_{2}$ phase. As observed in Fig. 1 for $\mathrm{Ce}_{0.81} \mathrm{Y}_{0.16} \mathrm{~W}_{0.03} \mathrm{O}_{1.95} \square_{0.05}(\mathrm{x}=0.19)$ as well as for other compositions, the XRD analysis confirms the amorphous character of the product after calcination at $250{ }^{\circ} \mathrm{C}$. It presents a black color due to residual organics. At $400{ }^{\circ} \mathrm{C}$ most of the organics burn out and the powder turns yellow; broad diffraction peaks are visible and can be attributed to a cubic fluorite-type phase. With increasing the calcination temperature, the width of the diffraction peaks progressively decreases while the color of the powder gradually changes from pale yellow to white. No phase transition or phase 
decomposition was observed in any of the studied stoichiometries. Fig. 2 gathers the powder diffraction patterns of the samples heated at $1000{ }^{\circ} \mathrm{C}$ for $15 \mathrm{~h}$. All the crystalline phases can be indexed in a cubic fluorite-type lattice with a shift of the diffraction lines towards higher angles with lowering the amount of cerium in the structure. The decrease in the crystallization state from $\mathrm{CeO}_{2}$ to $\mathrm{Y}_{6} \mathrm{WO}_{12} \square_{2}$ could be attributed to an increase of the metastable character when the composition gets closer to the one of the pure yttrium tungstate. Fig. 3 mentions that the variation of the lattice parameters with the chemical composition follows a Vegard's law and proves the existence of a cubic fluorite-type solid solution domain between the end terms $\mathrm{CeO}_{2}$ and $\mathrm{Y}_{0.86} \mathrm{~W}_{0.14} \mathrm{O}_{1.71} \square_{0.29}\left(1 / 7 \mathrm{Y}_{6} \mathrm{WO}_{12} \square_{2}\right)$. The cubic lattice parameters are a = 5,407(1) $\AA, 5,396(1) \AA$, $5,368(2) \AA 5,328(3) \AA$ and 5,292(4) $\AA$ for $x=0$ to 1 , respectively. The cubic symmetry implies fully disordered distributions on both the cationic and the anionic sub-network as observed in the case of the yttrium tungstate [6]. As a direct consequence, $\mathrm{Ce}^{4+}, \mathrm{Y}^{3+}$ and $\mathrm{W}^{6+}$ should occupy the same crystallographic site despite of the difference in their ionic radii $\left(\mathrm{r}_{\mathrm{Ce} 4+}\right.$ is 0.97 in 8-fold coordination, $\mathrm{r}_{\mathrm{Y} 3+}$ is 0.96 and 1.02 in 7- and 8-fold coordination, respectively, and $\mathrm{r}_{\mathrm{W} 6+} \sim \mathrm{r}_{\mathrm{Mo6+}}=$ 0.73 in 7-fold coordination [22]). In the case of cubic $\mathrm{Y}_{6} \mathrm{WO}_{12} \square_{2}$, the average coordination number for the cations in a defect cubic site is 6.86 , a value that progressively increases to 8 for a regular cubic site in the ceria.

Diffuse reflectance spectra and characteristic values of the samples heated at $1000{ }^{\circ} \mathrm{C}$ for 15 $\mathrm{h}$ are shown in Figure 4 and Table 1 respectively. All the compositions are characterized by a steep absorption edge with an average selectivity of $30 \mathrm{~nm}$. An important red shift is observed once substituting the yttrium tungstate $(\lambda=339 \mathrm{~nm})$ by cerium. All the corresponding substituted compositions present an absorption edge in the same wavelength range ( $380<\lambda<400 \mathrm{~nm}$ ). In an attempt to understand the non-linear variation of the bandgap (Fig. 5), the knowledge of the band structure of both limit compounds, $\mathrm{Y}_{6} \mathrm{WO}_{12} \square_{2}$ and $\mathrm{CeO}_{2}$, needs to be considered first.

The determination of DOS curves for the ordered rhombohedral phase $\mathrm{Y}_{6} \mathrm{WO}_{12} \square_{2}$ were made in a previous work using the density functional theory (DFT) [23]. The bandgap of this phase was determined to be $3.91 \mathrm{eV}$. The valence band (VB) presents essentially a $2 \mathrm{p}(\mathrm{O})$ character while the conduction band (CB) is mainly due to the contributions of $5 \mathrm{~d}(\mathrm{~W})$ orbitals. The $4 \mathrm{~d}(\mathrm{Y})$ band is located at higher energies and is not involved in the optical absorption process. Considering the cubic $\mathrm{Y}_{6} \mathrm{WO}_{12} \square_{2}$ discussed here, we can assume that the bands configuration should be similar to that of the rhombohedral phase. However, the crystallographic changes in the cations environment and the random $\mathrm{Y}^{3+} / \mathrm{W}^{6+}$ and $\mathrm{O}^{2-} /$ vacancies distributions in the structure could slightly affect the position and the width of both the conduction and valence bands leading to a lower observed bandgap $(\mathrm{Eg}=3.74 \mathrm{eV})$. In the case of ceria, band structure calculations show that the VB has 
mainly a $2 \mathrm{p}(\mathrm{O})$ character and the $\mathrm{CB}$ is essentially $5 \mathrm{~d}(\mathrm{Ce})$ in character [24]. The gap between the two bands is given to be about $5.75 \mathrm{eV}$. However, the $4 \mathrm{f}$-block band that is empty for $\mathrm{Ce}^{4+}$ lies between the $\mathrm{VB}$ and $\mathrm{CB}$ and then the experimental optical gap, i.e. $\mathrm{Eg}=3.19 \mathrm{eV}$ is attributed to a $2 \mathrm{p}(\mathrm{O}) \rightarrow 4 \mathrm{f}(\mathrm{Ce})$ charge transfer.

In the case of the substituted compositions in the $\mathrm{CeO}_{2}-\mathrm{Y}_{6} \mathrm{WO}_{12} \square_{2}$ system, the following assumption can be done: the $\mathrm{CB}$ should progressively move from the $5 \mathrm{~d}(\mathrm{Ce})$ band to the $5 \mathrm{~d}(\mathrm{~W})$ band position with decreasing the cerium amount in the structure, additionally the $4 \mathrm{f}$-block band lies in the gap between the VB and CB and its position should not be modified too much along the solid solution. That means that the optical band gap observed for all the substituted compositions occurs between the $2 \mathrm{p}(\mathrm{O})$ orbitals band and the $4 \mathrm{f}(\mathrm{Ce})$ band as illustrated in Fig. 6. The slight variation in the gap values from $\mathrm{CeO}_{2}(\mathrm{Eg}=3.19 \mathrm{eV})$ to $\mathrm{Ce}_{0.30} \mathrm{Y}_{0.60} \mathrm{~W}_{0.10} \mathrm{O}_{1.84} \square_{0.16}(\mathrm{Eg}=3.31 \mathrm{eV})$ could be attributed to some changes in the position and width of the valence band due to the introduction of vacancies in the anionic sub-network which causes a modification of the cations environment. This can be a possible explanation for the important redshift that is observed on the diffuse reflectance spectra between the yttrium tungstate and the Ce-containing compositions.

As no data were found in the literature, the refractive index of $\mathrm{Y}_{6} \mathrm{WO}_{12}$ was estimated using the Gladstone-Dale relation $\left(\mathrm{a}_{\mathrm{i}}\left(\mathrm{Y}_{2} \mathrm{O}_{3}\right)=0.170, \mathrm{a}_{\mathrm{i}}\left(\mathrm{WO}_{3}\right)=0.171\right.$ [17]). The calculated value $(\mathrm{n}=$ 2.00) appears to be slightly lower than that of $\mathrm{CeO}_{2}(\mathrm{n}=2.2$ [9]). Table 2 also gives, as a comparison, the evolution of the estimated values along with the solid solution. By comparison to the main marketed inorganic UV absorbers, especially $\mathrm{TiO}_{2}(\mathrm{n}=2.7$ for rutile and 2.5 for anatase), the refractive indexes calculated for the $\mathrm{CeO}_{2}-\mathrm{Y}_{6} \mathrm{WO}_{12}$ solid solution are interesting and let figure less whitening troubles considering the dispersion of the powders into a clear and colorless application medium.

The above results point out that the three substituted compositions manifest a strong absorption for the UV light with an absorption edge located between 380 and $400 \mathrm{~nm}$, and that the expected refractive indexes are lower than that of ceria. In order to fully determine their potential as inorganic UV absorbers, their photocatalytic behavior need to be characterized. TRMC and phenol photodegradation analyses were carried out on the $\mathrm{Ce}_{0.81} \mathrm{Y}_{0.16} \mathrm{~W}_{0.03} \mathrm{O}_{1.95} \square_{0.05}$ composition for which the absorption edge is the closest from $400 \mathrm{~nm}$ (UV/Visible transition). TRMC results indicate that no charge carriers were created under UV irradiation. For comparison, when $\mathrm{TiO}_{2}$ is illuminated with UV light, the photon energy is high enough so that an electron of the valence band can move to a level of the conduction band. It results the formation of a electron/hole pair. If these charge carriers do not recombine in the bulk, they can migrate to the surface and be trapped by metallic or 
oxygen ions [25]. The trapped charge carriers react with $\mathrm{O}_{2}$ and $\mathrm{H}_{2} \mathrm{O}$ to form free radicals which are very oxidative species able to decompose any present organic compounds into $\mathrm{CO}_{2}$ and $\mathrm{H}_{2} \mathrm{O}$. The fact that no charge carriers were observed in the case of $\mathrm{Ce}_{0.81} \mathrm{Y}_{0.16} \mathrm{~W}_{0.03} \mathrm{O}_{1.95} \square 0.05$ lets suppose that this composition does not exhibit any photocatalytic activity. This result is confirmed by the phenol photodegradation test (Figure 7). The absorption spectra of samples withdrawn after various reaction times, do not reveal any degradation of the phenol. For information, the phenol which has an absorption band between 240 and $290 \mathrm{~nm}$ does not decompose by itself under UV illumination. But in the presence of a photocatalytic material such as $\mathrm{TiO}_{2}$, it decomposes into hydroquinone which absorbs between 250 and $310 \mathrm{~nm}$ and benzoquinone which strongly absorbs for $\lambda<260 \mathrm{~nm}$. Additionally the diminution in the phenol concentration results in a decrease in its absorption band [21]. As none of the quinones bands are observed in the case of the $\mathrm{Ce}_{0.81} \mathrm{Y}_{0.16} \mathrm{~W}_{0.03} \mathrm{O}_{1.95} \square 0.05$ composition, we have concluded that this material does not manifest any photocatalytic behavior although $\mathrm{CeO}_{2}$ is given to have some photocatalytic activity [12]. The progressive introduction of vacancies in the anionic network along the $\mathrm{CeO}_{2}-\mathrm{Y}_{6} \mathrm{WO}_{12}$ solid solution can provide a possible explanation for this result. We assume that the anionic vacancies act like a trap for the charge carriers that can then quickly recombine. So they cannot reach the surface of the materials to induce the formation of free radicals, responsible for the decomposition of organics such as phenol.

\section{Conclusion}

Using the amorphous citrate route, potential inorganic UV-absorbing materials have been synthesized in the $\mathrm{CeO}_{2}-\mathrm{Y}_{6} \mathrm{WO}_{12}$ system in which a complete cubic fluorite-type solid solution was evidenced between the end members. All the substituted compositions manifest a strong absorption in the 380-400 nm range with estimated refractive indexes between 2.0 and 2.2, lower than those of $\mathrm{TiO}_{2}$ and $\mathrm{CeO}_{2}$. The presence of anionic vacancies in their structure that acts as a trap for the charge carriers can explain the absence of photocatalytic activity for the $\mathrm{Ce}_{0.81} \mathrm{Y}_{0.16} \mathrm{~W}_{0.03} \mathrm{O}_{1.95} \square_{0.05}$ phase, a behavior also expected for the other substituted compositions.

\section{Acknowledgment}

The French "Ministère de l'Economie et des Finances" supported financially the program AUVIB ( $\mathrm{N}^{\circ} 02490$ 6002) belonging to the Réseau National Matériaux et Procédés (RNMP). www.reseau-materiaux.com.fr. 


\section{References}

[1] J.-C. Boivin, Int. J. Inorg. Mater. 2001, 3, 1261-1266.

[2] B. Basu, Int. Mater. Reviews 2005, 50(4), 239-256.

[3] N. Diot, P. Bénard-Rocherullé, R. Marchand, Powder Diffr. 2000, 15(4), 220-226.

[4] H. J. Borschart, Inorg. Chem. 1963, 2, 170-173.

[5] K. Kuribayashi, M. Yoshimura, T. Ohta, Sata T., J. Am. Ceram. Soc. 1980, 63(11-12), 644646.

[6] M. Yoshimura, J. Ma, M. Kakihana, J. Amer. Ceram. Soc. 1998, 81(10), 2721-2724.

[7] J. Ma, M. Yoshimura, M. Kakihana, M. Yashima, J. Mater. Res. 1998, 13(4), 939-943.

[8] F. Tessier, R. Marchand, J. Solid State Chem. 2003, 171, 143-151.

[9] T. Masui, M. Yamamoto, T. Sakata, H. Mori, G. Adachi, J. Mater. Chem. 2000, 10, 353357.

[10] T. Masui, K. Fujiwara, K. Machida, G. Adachi, Chem. Mater. 1997, 9, 2197-2204.

[11] S. Yabe, S. Momose, J. Soc. Cosmet. Chem. Jpn. 1998, 32, 372-378.

[12] R. Li, S. Yabe, M. Yamashita, S. Momose, S. Yoshida, S. Yin, T. Sato, Mater. Chem. Phys. 2002, 75, 39-44.

[13] S. Yabe, M. Yamashita, S. Momose, K. Tahira, S. Yoshida, R. Li, S. Yin, T. Sato, Int. J. Inorg. Mat. 2001, 3, 1003-1008.

[14] A. Douy, P. Odier, Mater. Res. Bull. 1989, 24, 1119-1126.

[15] A. Boultif, D. Louer, J. Appl. Cryst. 2004, 37, 724-731.

[16] D. Kubelka, L. Munk, Z. Teck. Physik. 1931, 12, 593-601.

[17] R. Newnham, Structure-Property relations, Springer 1994.

[18] J. A. Mandarino, Can. Miner. 1981, 19, 441-450.

[19] H. W. Jaffe, Amer. Mineral., 1956, 41, 757-777.

[20] C. Colbeau-Justin, M. Kunst, D. Huguenin, J. Mater. Chem. 2003, 38, 2429-2437. 
[21] C. A. Emilio, M. I. Litter, M. Kunst, M. Bouchard, C. Colbeau-Justin, Langmuir 2006, 22(8), 3606-3613.

[22] R. D. Shannon, Acta Cryst. 1976, A32, 751-767.

[23] O. Larcher, Thesis n 2259, Université de Rennes 1, France, 2001.

[24] F. Goubin, X. Rocquefelte, M.-H. Whangbo, Y. Montardi, R. Brec, S. Jobic, Chem. Mater. 2004, 16, 662-669.

[25] S. Boujday, F. Wünsch, P. Portes, J. F. Bocquet, C. Colbeau-Justin, Sol. Energy Mater. Sol. Cells 2004, 85, 421-433. 


\section{Figures and tables captions}

Figure 1: Evolution of the powder diffraction patterns with the calcination temperature for the $\mathrm{Ce}_{0.81} \mathrm{Y}_{0.16} \mathrm{~W}_{0.03} \mathrm{O}_{1.95} \square_{0.05}$ composition.

Figure 2: Powder diffraction patterns of the samples calcined at $1000^{\circ} \mathrm{C}$ for $15 \mathrm{~h}$.

Figure 3: Evolution of the lattice parameters in the solid solution $\mathrm{CeO}_{2}-\mathrm{Y}_{0.86} \mathrm{~W}_{0.14} \mathrm{O}_{1.71} \square_{0.29}$.

Figure 4: Diffuse reflectance spectra of the samples calcined at $1000^{\circ} \mathrm{C}$ for $15 \mathrm{~h}$.

Figure 5: Variation of the experimental bandgap along the $\mathrm{CeO}_{2}-\mathrm{Y}_{0.86} \mathrm{~W}_{0.14} \mathrm{O}_{1.71} \square 0.29$ solid solution.

Figure 6: Schematic for the evolution of the optical gap along the $\mathrm{CeO}_{2}-\mathrm{Y}_{0.86} \mathrm{~W}_{0.14} \mathrm{O}_{1.71} \square_{0.29}$ solid solution.

Figure 7: Phenol photodegradation test with the $\mathrm{Ce}_{0.81} \mathrm{Y}_{0.16} \mathrm{~W}_{0.03} \mathrm{O}_{1.95} \square_{0.05}$ composition.

Table 1: Characteristic values from the diffuse reflectance spectra.

Table 2: Refractive indexes calculated using the Gladstone-Dale formula. 
Figure 1

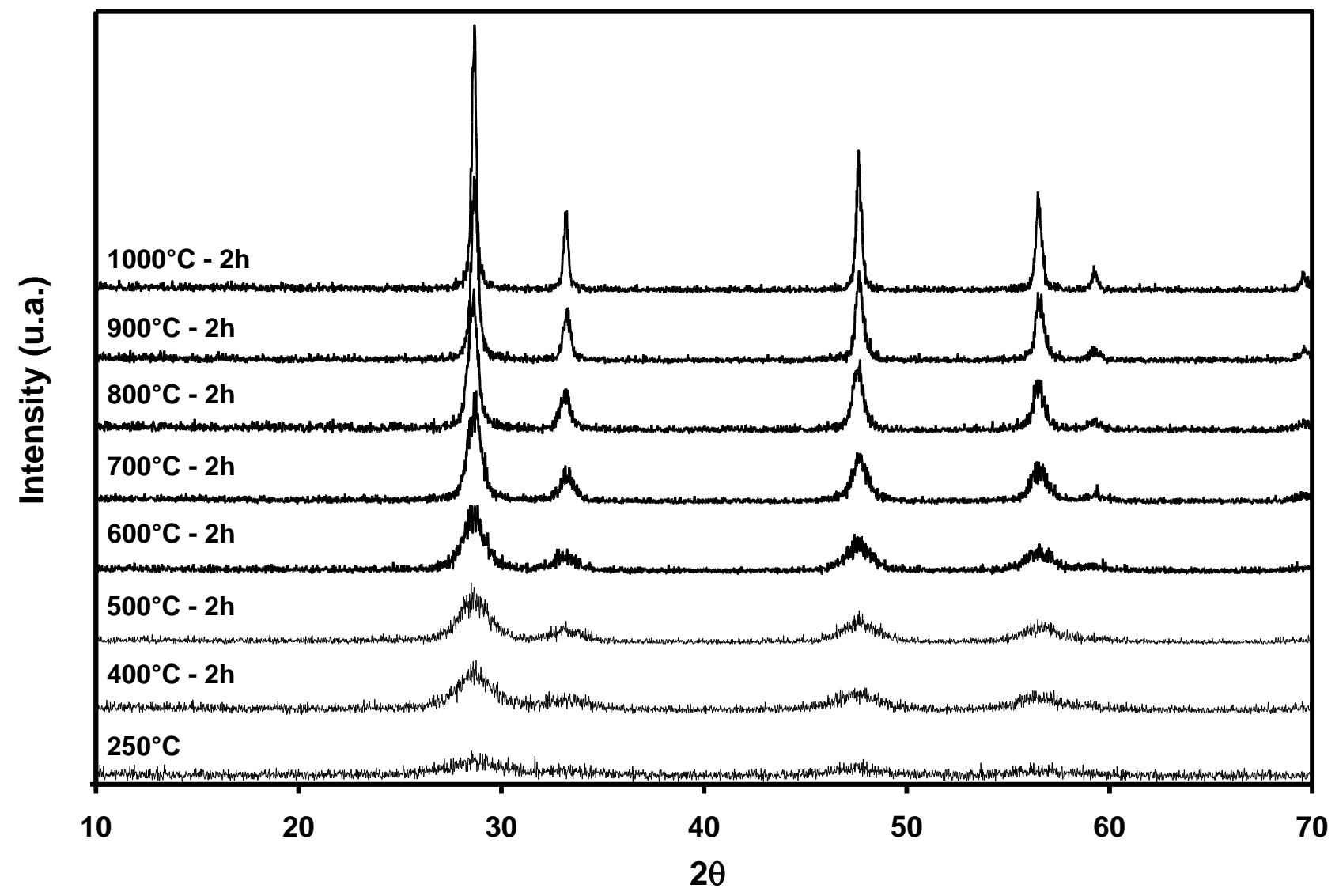


Figure 2

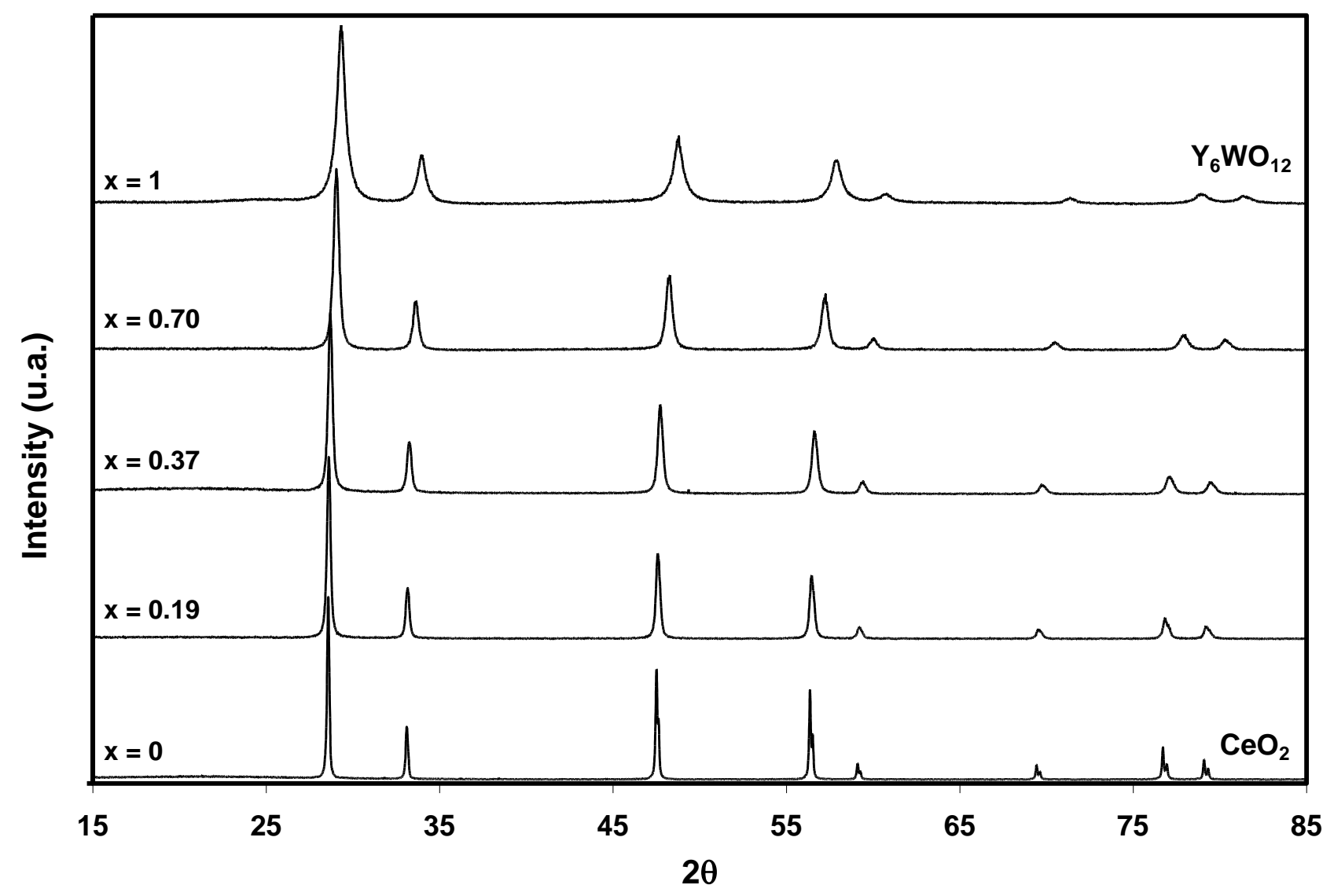


Figure 3

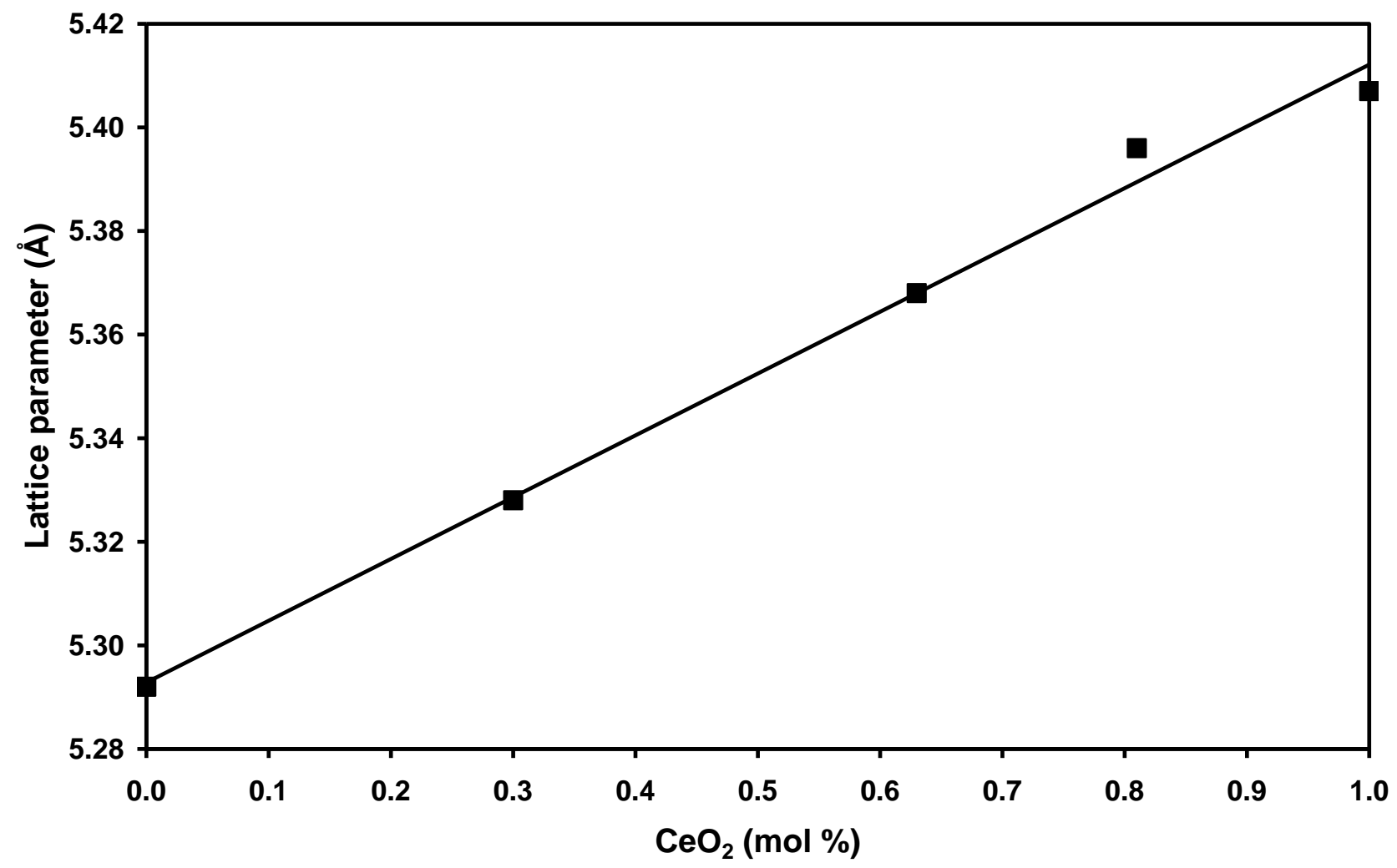


Figure 4

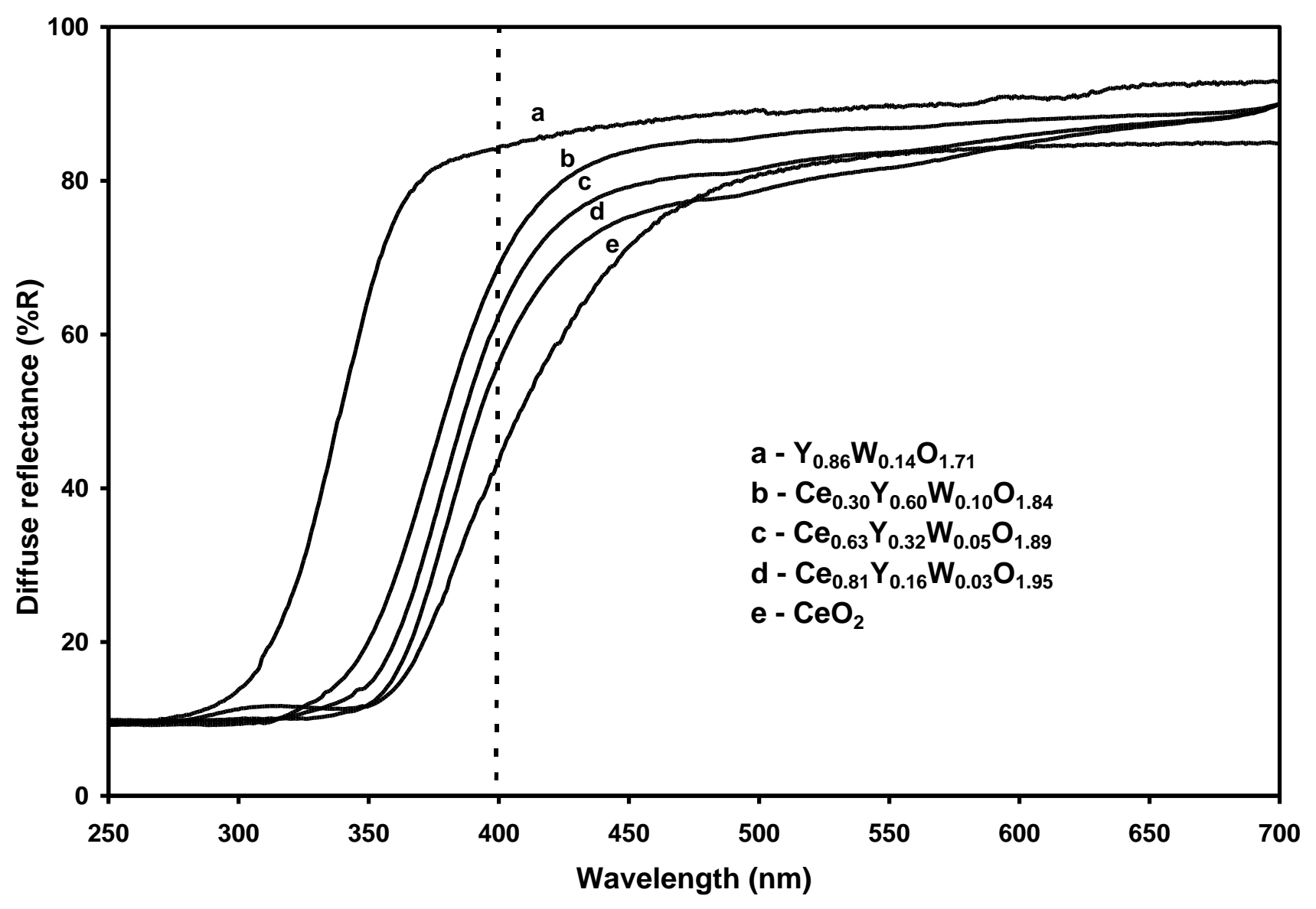


Figure 5

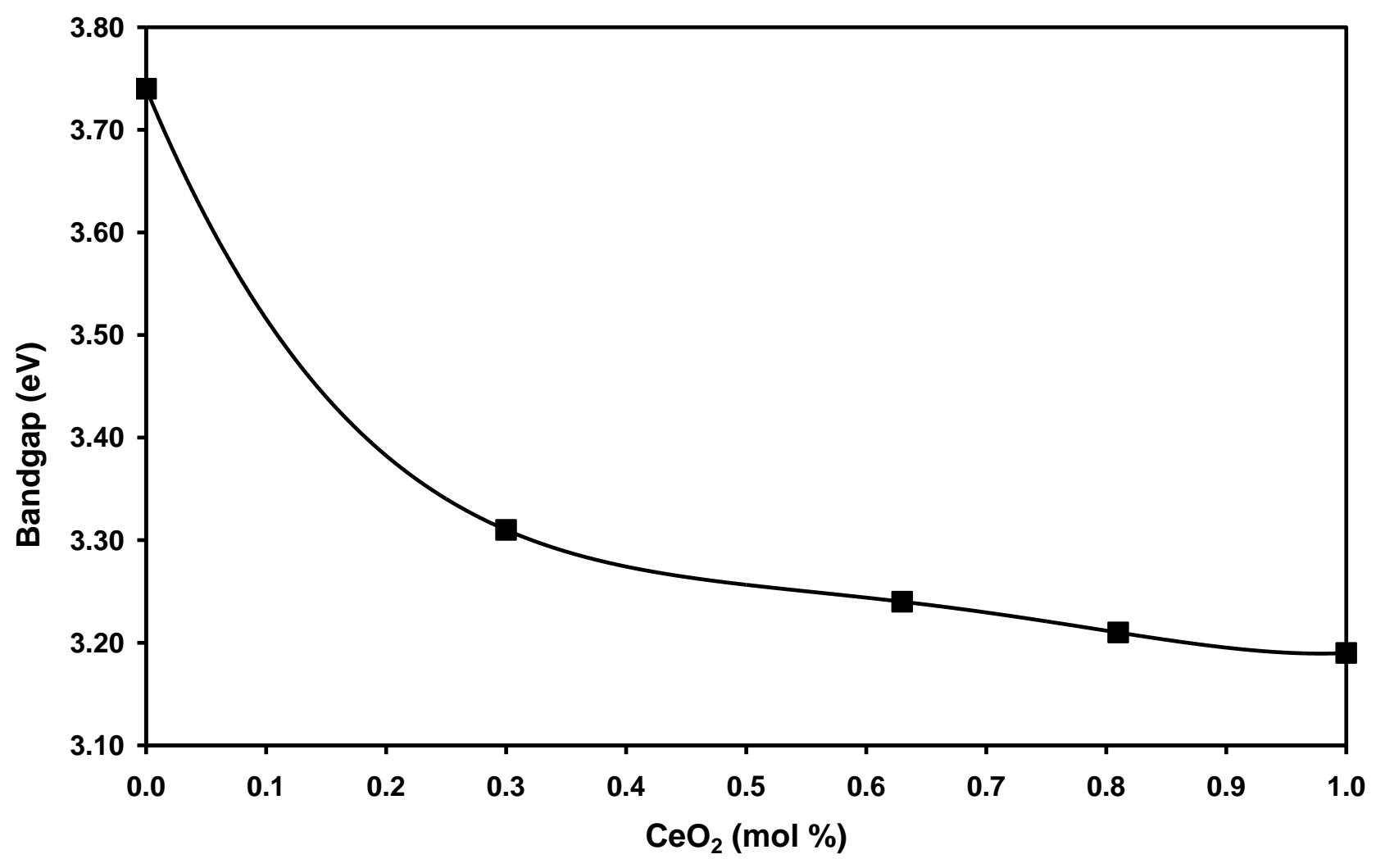


Figure 6

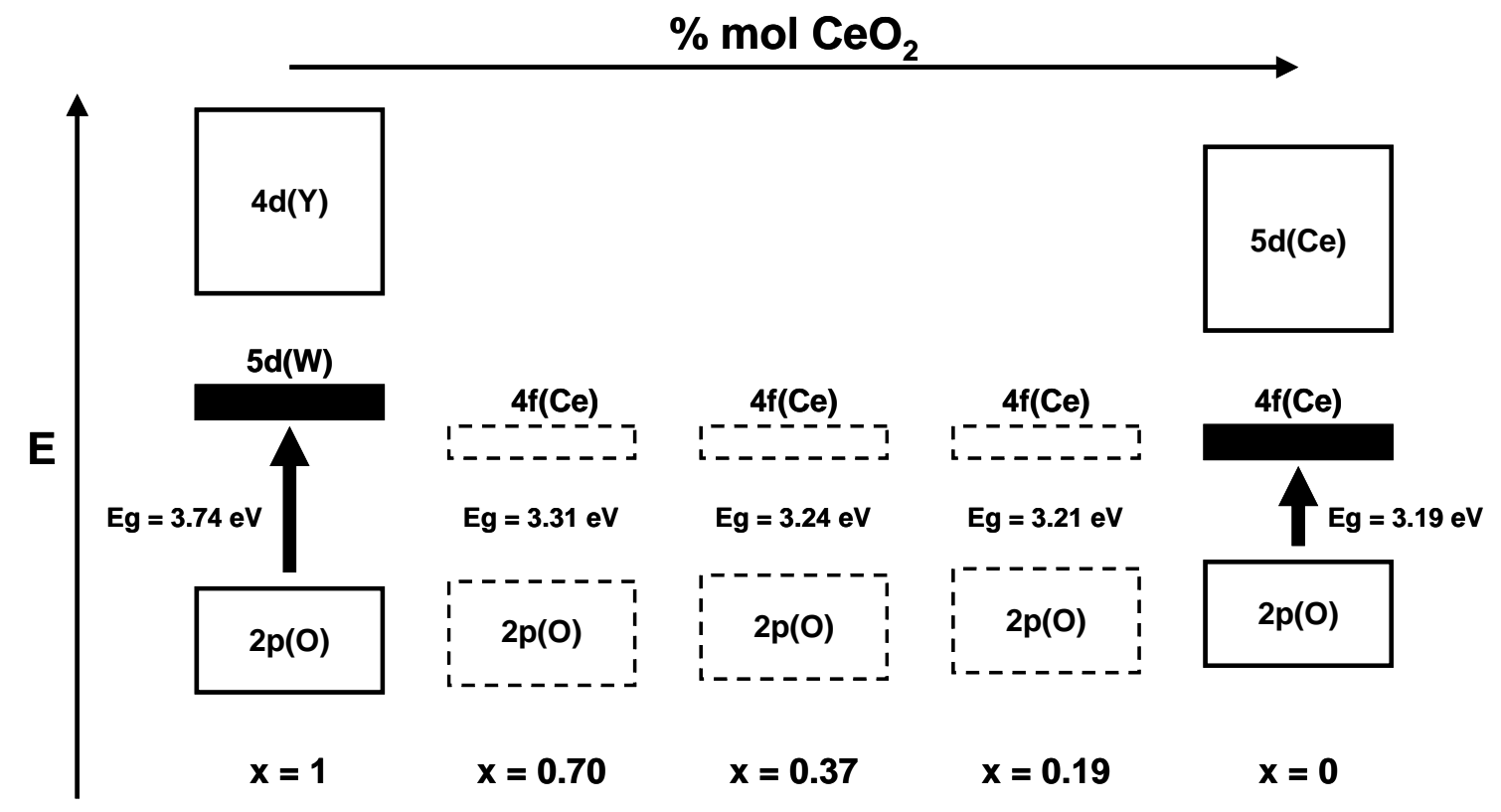


Figure 7

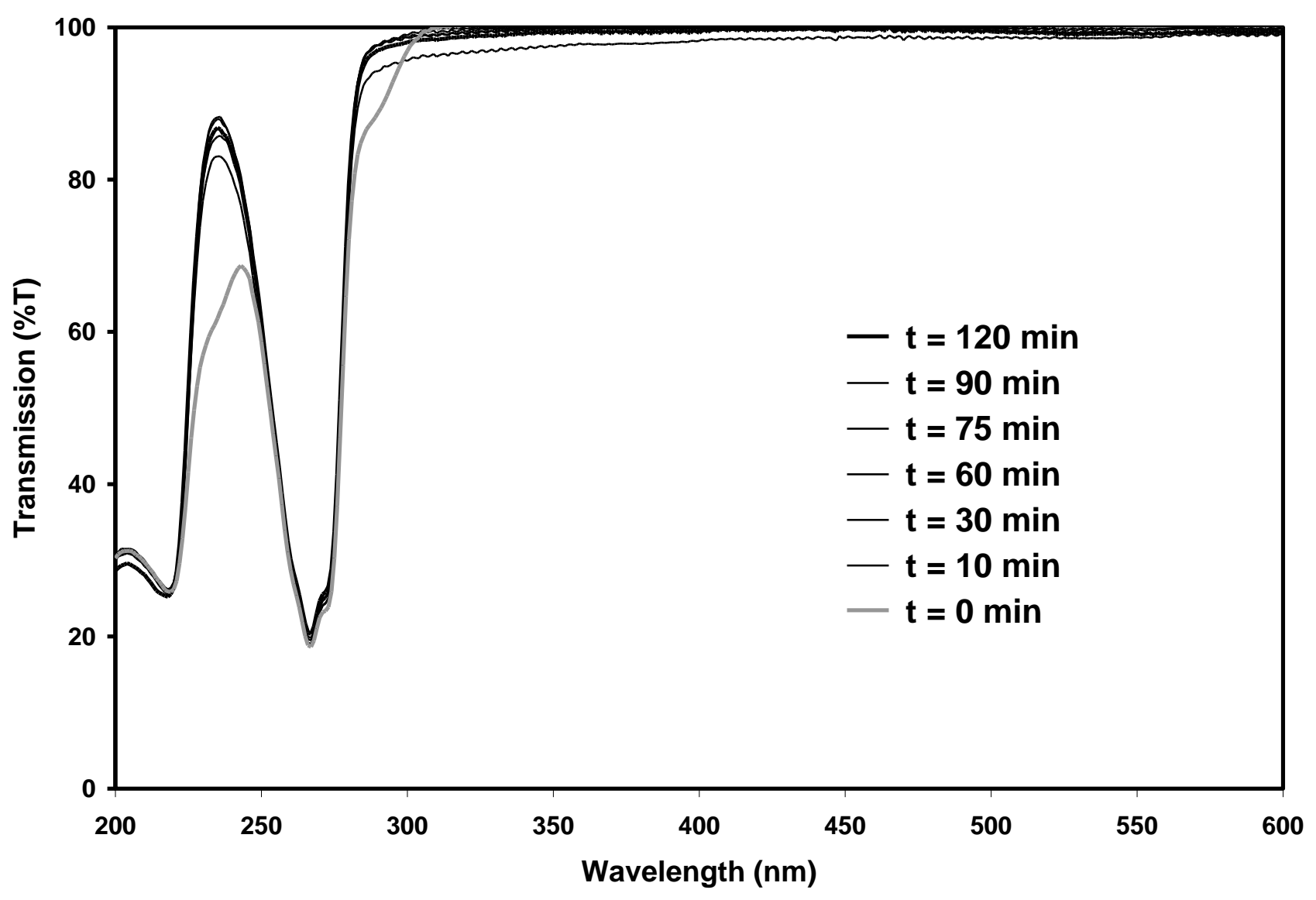


Table 1

\begin{tabular}{cccc}
\hline Composition & $\mathbf{x}$ & $\lambda \pm \Delta \lambda(\mathbf{n m})$ & $\mathrm{Eg}(\mathrm{eV})$ \\
\hline $\mathrm{CeO}_{2}$ & 0 & $388 \pm 30$ & 3.19 \\
$\mathrm{Ce}_{0.81} \mathrm{Y}_{0.16} \mathrm{~W}_{0.03} \mathrm{O}_{1.95} \square_{0.05}$ & 0.19 & $382 \pm 30$ & 3.21 \\
$\mathrm{Ce}_{0.63} \mathrm{Y}_{0.32} \mathrm{~W}_{0.05} \mathrm{O}_{1.89} \square_{0.11}$ & 0.37 & $379 \pm 31$ & 3.24 \\
$\mathrm{Ce}_{0.30} \mathrm{Y}_{0.60} \mathrm{~W}_{0.10} \mathrm{O}_{1.84} \square_{0.16}$ & 0.70 & $374 \pm 35$ & 3.31 \\
$\mathrm{Y}_{0.86} \mathrm{~W}_{0.14} \mathrm{O}_{1.71} \square_{0.29}$ & 1 & $339 \pm 30$ & 3.74 \\
\hline
\end{tabular}


Table 2

\begin{tabular}{cccc}
\hline Composition & $\mathbf{x}$ & density $^{* *}$ & $\mathbf{n}$ \\
\hline $\mathrm{CeO}_{2}$ & 0 & 7.215 & $2.20^{*}$ \\
$\mathrm{Ce}_{0.81} \mathrm{Y}_{0.16} \mathrm{~W}_{0.03} \mathrm{O}_{1.95} \square_{0.05}$ & 0.19 & 6.965 & 2.17 \\
$\mathrm{Ce}_{0.63} \mathrm{Y}_{0.32} \mathrm{~W}_{0.05} \mathrm{O}_{1.89} \square_{0.11}$ & 0.37 & 6.727 & 2.14 \\
$\mathrm{Ce}_{0.30} \mathrm{Y}_{0.60} \mathrm{~W}_{0.10} \mathrm{O}_{1.84} \square_{0.16}$ & 0.70 & 6.291 & 2.07 \\
$\mathrm{Y}_{0.86} \mathrm{~W}_{0.14} \mathrm{O}_{1.71} \square_{0.29}$ & 1 & 5.895 & 2.00 \\
\hline
\end{tabular}

* refraction coefficient value for $\mathrm{CeO}_{2}\left(a_{i}=0.166\right)$ was determined for $\mathrm{n}=2.2$.

** densities for substituted compositions were calculated using a linear correlation from the values of $\mathrm{CeO}_{2}$ and $\mathrm{Y}_{6} \mathrm{WO}_{12}$. 